УДК 005.21:316.7

DOI: https://doi.org/10.31866/2616-7573.2.2018.149470

ГРУШИНА Аліна Ігорівна, кандидат економічних наук, Київський національний університет культури і мистецтв, Київ, Україна, alinahrushyna@gmail.com

ORCID ID: https://orcid.org/0000-0002-5918-1833

\title{
ФОРМУВАННЯ СИСТЕМИ СТРАТЕГІЧНОГО УПРАВЛІННЯ В ГАЛУЗІ КУЛЬТУРИ
}

Анотація. Актуальність. Сьогодні вся інфраструктура галузі культури та мистецтва залежна від органів влади й перебуває у перманентному стані очікування щодо подальших структурних зрушень. Така система управління базується лише на пошуках можливості, уникаючи при цьому організації імпульсу знизу, своєрідного тиску на владні органи, з метою формування аргументованих і дійових пропозицій, що обумовлює актуальність дослідження. Mета і методи. Мета статті - дослідження процесів трансформації системи стратегічного управління в галузі культури впродовж становлення незалежності України. У дослідженні використано емпіричний і системний підходи, згідно 3 якими процеси управління у галузі культури, що застосовуються нині, проаналізовано у взаємозв'язку та розвитку. Також використано методи аналізу та синтезу. Результати. У ході аналізу еволюції, зокрема головних чинників розвитку, системи стратегічного управління в галузі культури було виокремлено ключові періоди, яким характерні ті чи інші фактори розвитку й гальмування. Відмічено наявність трансформаційних процесів упродовж становлення незалежності України до сьогодні. Висновки та обговорення. Наукова новизна одержаних результатів полягає у виокремленні та систематизації характерних факторів розвитку й гальмування створення системи стратегічного управління в галузі культури. Виділено чотири класифікаційні групи регіонів, що дає змогу ухвалювати рішення про доцільність подальших інвестицій у розвиток культури. Використання запропонованих підходів та практичних рекомендацій дозволить підвищити ефективність стратегічного управління в галузі культури.

Ключові слова: стратегічне управління, соціокультурна діяльність, менеджмент, галузь культури.

Грушина Алина Игоревна, кандидат экономических наук, Киевский национальный университет культуры и искусств, Киев, Украина

Формирование системы стратегического управления в сфере культуры

Аннотация. Актуальность. Сегодня вся инфраструктура области культуры и искусства зависит от органов власти и находится в перманентном состоянии ожидания относительно дальнейших структурных сдвигов. Такая система управления базируется только на поисках возможности, избегая при этом организации импульса снизу, своеобразного давления на органы власти с целью формирования аргументированных и действенных предложений, что обусловливает актуальность 
исследования. Цель и методыл. Цель статьи - исследование процессов трансформации системы стратегического управления в области культуры на протяжении становления независимости Украины. В исследовании использованы эмпирический и системный подходы, согласно которым процессы управления в области культуры, применяемые в настоящее время, проанализированы во взаимосвязи и развитии. Также использованы методы анализа и синтеза. Результаты. В ходе анализа эволюции, в частности главных факторов развития, системы стратегического управления в области культуры были выделены ключевые периоды, которым характерны те или иные факторы развития и торможения. Отмечено наличие трансформационных процессов на протяжении становления независимости Украины по сей день. Bblводы и обсуждение. Научная новизна исследования заключается в выделении и систематизации характерных факторов развития и торможения создания системы стратегического управления в области культуры. Выделены четыре классификационные группы регионов, что позволяет принимать решение о целесообразности дальнейших инвестиций в развитие культуры. Использование предложенных подходов и практических рекомендаций позволит повысить эффективность стратегического управления в области культуры.

Ключевые слова: стратегическое управление, социокультурная деятельность, менеджмент, сфера культуры.

Hrushyna Alina, PhD (Economics), Kyiv National University of Culture and Arts, Kyiv, Ukraine

Formation of the system of strategic management in the field of culture

Abstract. Actuality. Today, the entire infrastructure in the field of culture and art is dependent on the authorities and it is in a permanent state of expectation for further structural changes. Such a management system is based only on the search for opportunities, while avoiding the organization of impulse from below, a peculiar pressure on the authorities, in order to formulate reasoned and effective proposals, which determines the relevance of the study. Purpose and methods. The purpose of the article is to explore the processes of transformation in the system of strategic management in the field of culture during the Ukraine's independence formation. The article has used empirical and systematic approaches, according to which the processes of management in the field of culture currently used, they are analyzed in the relationship and development. Methods of analysis and synthesis are also used. Results. During the analysis of evolution, in particular, the main factors of development, the system of strategic management in the field of culture, the key periods have been distinguished, which are characterized by certain factors of development and inhibition. The presence of transformation processes during the formation of Ukraine's independence for today is noted. Conclusions and discussion. The scientific novelty of the obtained results is to isolate and systematize the characteristic factors of development and inhibition of the creation of a strategic management system in the cultural field. Four classification of the regions are allocated, which makes it possible to decide on the expediency of further investments in cultural development. The use of the proposed approaches and practical recommendations will enhance the effectiveness of strategic management in the cultural field.

Keywords: strategic management, socio-cultural activity, management, culture. 


\section{1. Актуальність проблеми Actuality of problem}

В умовах формування нової соціально-економічної реальності не можна уявити повноцінного розвитку суспільства без провадження процесу розвитку галузі культури в Україні. Найбільшою мірою актуальність дослідження обумовлена такими причинами, як: нівелювання ролі держави у реалізації задекларованих нею першочергових завдань реформування підприємств галузі культури; недостатній обсяг фінансових ресурсів Державного бюджету України, передбачений на функціонування закладів культури; відсутність концептуальних стратегій у контексті належного позиціонування сфери культури як пріоритетної галузі національної економіки України; зростання впливу негативних зовнішніх та внутрішніх тенденцій. Враховуючи вище зазначене, на особливу увагу заслуговує проблема подальшого поглиблення теоретичних засад, які б допомогли з'ясувати основні характеристичні ознаки системи стратегічного управління, де об'єктом виступає галузь культури, а також сприяли розробці методичного інструментарію щодо підходів і механізмів їх використання.

Стан вивчення проблеми. Значний обсяг роботи за цією проблематикою було проведено ЮНЕСКО, який викладений у доповіді «Funding Culture, Managing the Risk». Це питання розглядали також учені різних галузей науки через багатство призм. Наприклад, саме державне регулювання підтримки закладів культури здійснювалося неодноразово зарубіжними й українськими науковцями, такими як О. Антонюк (2011), А. Візанд (2015), Г. Костандаке (Costandace, 2014), Г. Піньковська (2014), Г. Скрипчук (2011), Дж. Стігліц (1998), Р. Фішер (Fisher, 1994) та ін.

Невирішені питання. Однак сучасні умови вимагають перегляду основних положень науки й адаптації їх до сьогодення. Занепад закладів культури як базису розвитку галузі культури та мистецтва зумовлений відсутністю відповідного механізму стратегічного управління в галузі культури, а мінімізація фінансової підтримки позбавляє їх життєздатності. Отже, сьогодні недостатньо досліджено процес формування системи стратегічного управління в галузі культури як основи соціальноекономічного зростання країни.

\section{2. Мета і методи дослідження Purpose and methods of research}

Мета статті - дослідження процесів трансформації системи стратегічного управління в галузі культури впродовж становлення незалежності України. 
Методологічною основою дослідження є діалектичний, системний та історичний підходи до вивчення економічних процесів, фундаментальні положення економічної теорії, наукові здобутки провідних вчених, присвячені проблемам управління в галузі культури.

У ході дослідження використано загальнонаукові методи пізнання економічних явищ і процесів, такі як історичний метод, абстрактнологічний та метод аналізу - при узагальненні наукових концепцій менеджменту в галузі культури, системного підходу при узагальненні наявних підходів щодо стратегічного управління культурно-мистецьким комплексом. При виокремленні особливостей системи менеджменту в галузі культури використано спектр методів, притаманних теоретичному й емпіричному рівням наукового пізнання.

Інформаційною базою дослідження слугують положення економічної й управлінської теорій, наукові праці провідних вітчизняних і зарубіжних вчених щодо управління в галузі культури, а також нормативно-законодавчі акти та результати власних досліджень автора.

\section{3. Результати дослідження Research results}

Сьогодні вся інфраструктура галузі культури і мистецтва залежна від органів влади та перебуває у перманентному стані очікування щодо подальших структурних зрушень. Така система управління базується лише на пошуках можливості, уникаючи при цьому організації імпульсу знизу, своєрідного тиску на владні органи з метою формування аргументованих і дійових пропозицій.

Дослідник О. Антонюк (2012) зазначає, що сучасна парадигма менеджменту галузі культури і мистецтва передбачає активне впровадження аналітичних підходів в управління, зокрема, стратегічного, цільового, яке в контексті нашого дослідження має бути націлене на формування адекватної структури фінансових ресурсів підприємств культури як базису їх ефективного функціонування. Науковець дотримується думки про необхідність державного управління в регулюванні відносин усередині культурно-мистецького комплексу з одночасною активізацією управління на регіональному, муніципальному рівні та на рівні самоврядування, формуванням при цьому дійової системи відбору й підготовки професійних управлінських кадрів (с. 104).

Так, він схильний вважати, що управління соціокультурною сферою сьогодні відбувається дещо іншими методами і способами, аніж за часів Радянського Союзу, яке опирається при цьому на ідеологічний плюралізм і безпосередню творчу участь громадян у культурному житті суспільства (Там само, с. 105). Тобто, замість державної регламентації 
процесів у сфері культури та мистецтва, усі владні структури спрямовані на іiї підтримку, що, на думку науковця, є хибним і потребує переосмислення та зміни стилю управління загалом (Грушина, 2017).

Г. Скрипчук свого часу приділяв чимало уваги аналізу стану сфери культури. В одній зі своїх наукових робіт дослідник проводить зіставлення систем і типів управління культурно-мистецьким комплексом у часи СРСР та на етапі становлення незалежної України. На думку вченого, ідейне наповнення змісту культури в часи СРСР мало суто ідеологічне спрямування, зумовлене всебічним контролем із боку держави та партії. Характерний у ті часи державний патерналізм проявлявся в усіх секторах економіки, культури зокрема. Заклади культури всіх типів фінансувала виключно держава, а незначні видатки задовольняли мінімальні потреби культурно-мистецького комплексу. Але, попри виконання мінімальних умов, проводилося капітальне будівництво, купувався реквізит, музичні інструменти, інвентар, виплачувалися заробітні плати (Скрипчук, 2011, 2012).

Для радянських часів у системі управління галуззю культури і іiі фінансовим забезпеченням характерними $є$ іiї вертикальність і значна розгалуженість. В основі такої системи було Міністерство культури, яке, попри свій вагомий статус, повністю й беззаперечно підпорядковувалось панівному на той час соціально-економічному та політичному режиму. Держава повністю опікувалась культурно-мистецьким комплексом, забезпечувала відповідне фінансування в усіх напрямах діяльності культури від охорони пам'яток культури в містах до будівництва клубів у сільських місцевостях, що забезпечило розвиток інфраструктури мережі закладів культури (Грушина, 2017).

Так, зіставивши сьогодні показники витрат домогосподарств на алкоголь і культуру, можемо зробити висновок про те, що в структурі доходу витрати, до прикладу, на алкоголь у 2002-2017 рр. є більш пріоритетними, аніж витрати на культурний розвиток населення, які коливаються в межах 1,9-2,6\%, а 2017 р. сягнули рівня 1,0\%, що значно нижче рівня 2002 р. (Державна служба статистики..., 2017).

На послуги культурно-мистецького сектору середньостатистична сім'я Радянського Союзу 1991 р. витрачала 3,4 \% від загального доходу, тоді як на купівлю алкогольних напоїв лише 2 \% (Статистичний щорічник..., 1992). Сума витрат домогосподарств на відпочинок і культуру, починаючи з 1992 р. донині, демонструє стійке зниження. Однозначним фактором впливу на суму витрат на культуру і відпочинок $\epsilon$ рівень економічного розвитку регіону.

До прикладу, якщо середньостатистична родина м. Києва 2017 р. витрачала на відпочинок і культурні блага 2,3 \%, то сім'я на Хмельниччині - лише 0,6 \% із загальної суми доходів (Державна служба статистики..., 2018). Проте в умовах економічної турбулентності можна при- 
пустити, що такий відсоток $є$ все-таки формальною цифрою. Звісно, така різниця зумовлена рівнем доходів населення згаданих вище регіонів $\mathrm{i}$ кількістю закладів культури на їх території (Costandace, 2014).

Так, інфляційні процеси впливають не лише на формування суми видатків на культуру, а й на активність населення з використання культурних благ. Таким чином, заклади культури, зокрема бібліотеки, концертні організації, театри і навіть демонстратори фільмів, із кожним роком стрімко втрачають потенційну аудиторію, що зумовлено зниженням рівня доходів громадян, якості їх життя й іншими негативними економічними чинниками.

За період 2010-2017 pр. (табл. 1) можна зробити висновок про незначний ріст активності населення щодо споживання культурних благ. Проте значення таблиці свідчать, що рівень коефіцієнта рівня відвідуваності 2017 р., попри незначний ріст на фоні 2014-2015 pp., $є$ нижчим від рівня 2010-2013 рр., з чого випливає висновок про незначні коливання в усталеній тенденції до зниження рівня активності населення в споживанні продукції та послуг галузі культури (виключення становили театри) (Державна служба статистики..., 2018).

Табл. 1. Відвідуваність населенням закладів і заходів культури в Україні

Tab. 1. Visiting population of institutions and cultural events in Ukraine

\begin{tabular}{|l|c|c|c|c|c|c|c|c|}
\hline \multirow{2}{*}{$\begin{array}{c}\text { Заклади } \\
\text { і заходи } \\
\text { культури }\end{array}$} & \multicolumn{6}{|c|}{ Рівень відвідування, у розрахунку на 100 осіб за роками } \\
\cline { 2 - 10 } & 2010 & 2011 & 2012 & 2013 & 2014 & 2015 & 2016 & 2017 \\
\hline Музеї & 41 & 42 & 44 & 43 & 33 & 35 & 37 & 39 \\
\hline Театри & 14 & 14 & 15 & 15 & 13 & 13 & 14 & 15 \\
\hline Концерти & 9 & 9 & 10 & 9 & 6 & 6 & 6 & 7 \\
\hline Кіносеанси & 19 & 33 & 35 & 29 & 25 & 25 & 25 & 25 \\
\hline
\end{tabular}

Джерело: складено автором за даними (Державна служба статистики..., 2018)

Source: developed on the basis of (State Statistics Service..., 2018)

У процесі аналізу сучасного стану й рівня розвитку інфраструктури галузі культури та мистецтва доцільно враховувати галузеву розбалансованість культурно-мистецького комплексу на регіональному рівні. Тобто важливим чинником розвитку культури в цілому залишається регіональна специфіка. Цей фактор має бути базовим у процесі трансформаційних перетворень галузі, а визначена нами регіональна відмінність - врахована при аналізі стану галузі культури (Fisher, 1994).

Таким чином, у межах аналізу стану стратегічного управління фінансовими ресурсами закладів культури важливим $€$ показник забезпеченості ними населення (кількість закладів культури на 100 тис. осіб). За офіційними даними Державної служби статистики (2018) та Міністерства культури України щодо забезпечення закладами культури на- 
селення станом на кінець 2017 р. можна зробити висновок про значний розрив у кількості закладів культури як за регіонами, так і в міських $\mathrm{i}$ сільських місцевостях.

Нами проаналізовано також рівень відвідуваності населенням закладів культури в розрізі регіонів із метою визначення активності населення відносно його чисельності за адміністративними одиницями.

На нашу думку, доцільно розрахувати коефіцієнт кількості відвідувачів у розрахунку на 100 осіб, що унеможливить чинник залежності від кількості населення при рейтингуванні областей і відтворить картину активності населення за регіонами. Це дозволить зіставити значення активності споживачів культурних благ відносно інфраструктури галузі забезпечення населення закладами культури.

У межах аналізу інфраструктурного забезпечення культурного середовища Г. Піньковська (2014) виділила у своїй роботі сім груп регіонів за рівнем їх культурного розвитку відповідно до рівня ефективності використання об'єктів культури.

Відповідно до зазначеного вище нами за допомогою зіставлення інтегрального коефіцієнта забезпеченості населення закладами культури й загального показника рівня активності населення щодо споживання культурного продукту побудовано систему координат із метою поділу регіонів за рівнем їх культурного розвитку та потенціалу.

Так, у рамках стратегічного управління фінансовими ресурсами як для держави, так і для інвесторів важливим є розуміння того, наскільки доцільно інвестувати в розвиток культурних індустрій у тому чи іншому місті. А тому важливим питанням залишається попит населення на культурний продукт і послуги, а також рівень конкуренції на ринку культури. Нами виділено чотири класифікаційні групи регіонів (рис. 1), які дають змогу прийняти рішення про доцільність подальших інвестицій у розвиток культури з боку держави й інвестора або ж їх припинення. При цьому враховується рівень забезпеченості населення закладами культури і його активність у споживанні культурного продукту. За нормативне значення зазначених коефіцієнтів узято середнє значення по регіонах України, що дозволило здійснити відповідну фільтрацію областей і виділити такі групи регіонів:

- культурно активні регіони - це регіони з високим і вище середнього рівня забезпеченості населення закладами культури, при високому рівні активності самого населення щодо споживання культурних благ. Такі адміністративні одиниці характеризуються, як правило, значною кількістю закладів культури, низькою чисельністю населення та значним попитом на культурні послуги, а тому потребують стабільної підтримки. Згідно з групуванням, до таких регіонів відносяться ІваноФранківська, Хмельницька, Тернопільська, Львівська, Чернігівська та Черкаська області; 


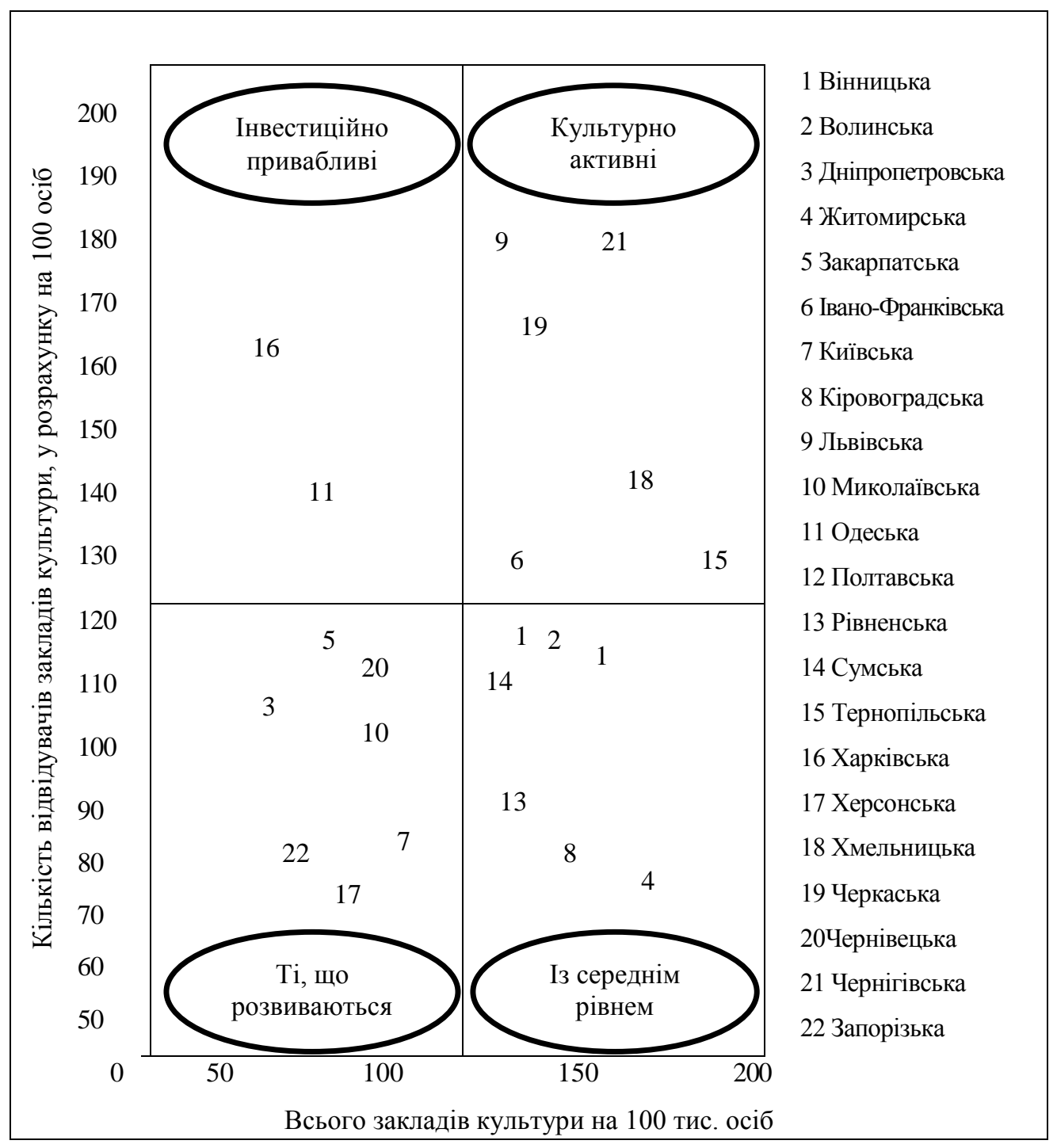

Puc. 1. Рейтингування закладів культури за активністю споживання культурних благ за регіонами України Джерело: розроблено автором

Fig. 1. Rituals of cultural institutions by activity of cultural goods consumption by regions of Ukraine

Source: own development

- інвестиційно привабливі регіони - регіони, які характеризуються високою активністю населення щодо споживання культурного продукту, попри невисокий рівень розвитку інфраструктури галузі культури та мистецтва. Тому галузь у зазначених регіонах $\epsilon$ інвестиційно привабливим і потенційно прибутковим сектором. Це, своєю чергою, 
дозволяє зробити висновок про доцільність бюджетних асигнувань $\mathrm{i}$ додаткових інвестицій у розвиток культурної індустрії, підприємств культури саме цих регіонів. Відповідно до групування інвестиційно привабливими є Харківська й Одеська області;

- регіони, які розвиваються, - це адміністративні одиниці, для яких характерний низький рівень активності й дещо нижчий рівень забезпеченості населення закладами культури. Згідно з цими критеріями можна зробити висновок, що за умови підвищення рівня забезпеченості закладами культури в регіонах, ефективної системи стратегічного управління фінансовими ресурсами можливо змінити рівень активності населення зі споживання культурних благ. За групуванням до таких регіонів належать Київська, Закарпатська, Чернівецька, Миколаївська, Херсонська, Запорізька та Дніпропетровська області;

- регіони із середнім рівнем активності - негативна група, для якої характерний наявний потенціал - розвинена інфраструктура галузі, але низький рівень активності населення щодо відвідування закладів культури. На нашу думку, така ситуація є результатом низького рівня соціально-економічного розвитку регіону. Проте можливий варіант, що забезпеченість закладами культури $є$ формальною, а підприємства перебувають у стані неповного функціонування. Звідси випливає цілком адекватна поведінка населення щодо низького рівня попиту. У групі неактивних регіонів опинилися Волинська, Рівненська, Вінницька, Кіровоградська, Полтавська, Сумська та Житомирська області. У ході аналізу структури витрат домогосподарств на відпочинок і культуру саме за визначеними областями спостерігається низький рівень витрат на культуру порівняно з іншими, виняток становлять Сумська й Полтавська області.

За таких обставин можемо робити висновок, що система стратегічного управління сферою культури перебуває у статичному стані.

Наявний у період існування Радянського Союзу державний патерналізм був ідеологічним, спрямованим на впровадження через культурну сферу та їі заклади політики держави й передусім радянського інтернаціоналізму. Звичайно, що така практика управлінського режиму має право на існування та поширена у світі, оскільки за такої системи управління основним завданням держави $\epsilon$ підтримка культурно-мистецького сектору, а тим більше некомерційного. Прикладом дійової системи управління культурою за рахунок патерналізму може бути Франція, яка $\epsilon$ однією із найрозвиненіших країн у культурному сенсі. Такі засади мали продовжувати діяти і в Україні в перші роки ії незалежності, у результаті проведених соціально-економічних реформ (Стігліц, 1998).

Проте економічна система України формувалась із проголошенням iii незалежності й переходом до ринкової економіки. Якщо детально 
аналізувати передумови витоків стану галузі культури, то відразу стає очевидним, що фактори низького рівня іiї розвитку поєднують у своїй основі об’єктивні й суб'єктивні детермінанти. Насамперед це проблема формування на місці архаїзмів радянської системи принципово нового ринкового середовища України. Після розпаду СРСР утворення нової незалежної держави повинно було супроводжуватися розробкою новітньої функції державного управління, пов'язаної з культурним розвитком, яке мало б узяти на себе обов'язки головного суб'єкта для вирішення гострих суспільних суперечностей і загроз у системі економічних відносин у процесі подолання глибинних криз як в економіці, так і в культурі (Грушина, 2017).

Таким чином, можна зробити висновок, що згадана розвинена інфраструктура, яка залишилась після розпаду СРСР, значною мірою технічно, морально й матеріально застаріла, а відповідно, потребувала капітального оновлення. I можна припустити, що в період розпаду СРСР Україна все-таки володіла значними ресурсами для подальшого розвитку галузі культури. За вчасного ухвалення стратегічних управлінських рішень щодо законодавчих регуляторів і політики фінансової підтримки галузі, в умовах ринкової економіки, культурно-мистецький комплекс міг пережити трансформаційні процеси й стати на новий шлях розвитку.

Але оскільки базова мережа комунальних і державних закладів культури звикла до застарілої системи державного управління, вона вимагала фінансування з боку держави в повному обсязі та провокувала подальше використання ідеологічних засобів, посівши при цьому пасивну позицію очікування щодо функціональних управлінських рішень із боку держави.

Отже, можна дійти очевидних висновків, що дослідження методів інноваційного вдосконалення державної системи управління і регулювання діяльністю підприємств галузі культури є важливим не лише 3 позицій культурно-духовної трансформації суспільства, а й у напрямі ідентифікації потенціалу очікуваних результатів соціально-економічного характеру за допомогою успішної інтеграції у світовий глобалізований культурний простір.

Постійні реформації галузі культури України відбуваються з часів іiї незалежності. Вони зумовлені потребою ліквідувати попередні радянські патерналістські й ідеологічні методи управління культурою, а також запровадити нову систему стратегічно орієнтованого управління культурномистецьким комплексом. Проте неймовірно повільні темпи розробки та реалізації реформ значною мірою гальмують процес розвитку і не 
відповідають викликам часу. Звичайно, така ситуація є результатом політичної нестабільності й економічної кризи в країні, що сповільнює процес розвитку будь-якого сектору національної економіки.

\section{4. Висновки та обговорення результатів Conclusions and discussion of results}

Результати проведеного дослідження у рамках аналізу підходів щодо стратегічного управління в галузі культури впродовж становлення незалежності України дозволили дійти наступних висновків:

1. Визначено, що на сьогодні стратегічна модель управління культурою все ж таки зазнала певних змін. Зокрема, у період становлення незалежності чинником стабільного занепаду була ідеологія компартії, засади якої донедавна лежали в основі системи управління культурою, нині таку загрозу складають євроінтеграційні процеси та глобалізація як фактори втрати культурної ідентичності, самобутності, відповідно, конкурентоспроможності культурного національного продукту.

2. У ході дослідження інфраструктури галузі культури виявлено, що мережа культури щорічно зменшується, активність населення щодо відвідування підприємств галузі культури знижується. Таке явище обумовлено як економічними факторами, так і специфікою кожного регіону.

3. Запропоновано рейтингування областей за рівнем їх культурної активності й розвитком мережі закладів культури, що дозволяє їх групувати. У результаті виокремлено культурно активні регіони, регіони, що розвиваються, інвестиційно-привабливі та регіони із середнім рівнем активності, що дає змогу ухвалювати рішення про доцільність подальших інвестицій у розвиток культури з боку держави й інвестора або ж про їх припинення. При цьому варто враховувати рівень забезпеченості населення закладами культури і його активність у споживанні культурного продукту.

Наукова новизна одержаних результатів полягає у виокремленні й систематизації характерних факторів розвитку та гальмування створення системи стратегічного управління закладами культури, а також рейтингування, на їх основі, областей за рівнем культурної активності й розвитком мережі закладів культури, що дозволяє їх групувати.

Практичне значення отриманих результатів виявляється у використанні основних підходів і рекомендацій щодо стратегічного управління в галузі культури, застосування яких дозволяє підвищувати ефективність іï функціонування.

Перспективами подальших досліджень у цьому напрямі може стати розробка вітчизняної системи стратегічного управління в галузі культури і мистецтв, адекватної сьогоднішнім умовам в Україні. 


\section{Література}

Антонюк О. В. Менеджмент культурно-мистецької сфери. Часопис Національної музичної академії України ім. П. І. Чайковського. 2011. № 2. C. 104-110.

Візанд А. Сучасні тенденції культурної політики в Свропі. Сучасні тендениії культурної політики в Свропі : семінар. Київ. 2015. URL: https:// www.youtube.com/watch?v=TbZCzweK_fY (дата звернення : 17.08.2018).

Грушина А. І. Аналіз розвитку системи стратегічного управління фінансовими ресурсами організацій сфери культури. Бізнес Інформ. 2017. № 1. C. 302-307.

Грушина А. І. Особливості організації системи менеджменту сфери культури та мистецтв. Вісник Київського національного університету культури i мистеитв. Серія: Менеджмент соиіокультурної діяльності. 2018. № 1. C. 53-63.

Державна служба статистики України. URL: http://www.ukrstat.gov.ua/ (дата звернення : 17.05.2018)

Піньковська Г. Оцінка сучасного стану розвитку культурного середовища регіонів України. Ефективна економіка. 2014. № 10. URL: http:// www.economy.nayka.com.ua/?op=1\&Z=3424 (дата звернення : 03.05.2018).

Скрипчук Г. В. Державне реформування культурної сфери України в умовах економічної та соціальної кризи 1991-2001 рр. : автореф. дис. ... канд. іст. наук : спец. 07.00.01. Харків, 2011. 20 с.

Скрипчук Г. В. Огляд стану культурно-мистецької сфери України на час становлення державної незалежності (1991р.). Вісник Харківської державної академії культури. 2012. Вип. 36. С. 12-21.

Статистичний щорічник України за 1991 рік. Державний комітет статистики України. За ред. В. В. Самченко. Київ : Техніка, 1992. 468 с.

Стігліц Дж. Е. Економіка державного сектора. Пер. $з$ англ. Київ : Основи, 1998. $114 \mathrm{c}$.

Costandace G. Analisis of mechanism financing of cultural sphere. Economy of Moldova. 2014. № 1. P. 102-114.

Fisher R. Introduction to the Position of Independent or Quasi Independent Agencies \& Foundations in Cultural Sector in Britain. A Report to the CIRCLE Round Table. London : Britain Publishers, 1994. P. 21-58.

Стаття надійшла до редакції 23.09.2018

\section{References}

Antoniuk, O. V. (2016). Menedzhment kulturno-mystetskoi sfery [Management of cultural and artistic sphere]. Chasopys Natsionalnoyi muzychnoyi akademiyi Ukrayiny im. P. I. Chaykovskoho [The journal of the National Music Academy of Ukraine named after. P. I. Tchaikovsky], 11, 104-110 (in Ukr.). 
Costandace, G. (2014). Analisis of mechanism financing of cultural sphere. Economy of Moldova, 1, 102-114.

Derzhavna sluzhba statystyky Ukrainy [The state statistics service of Ukraine]. (2017). Retrieved from http://www.ukrstat.gov.ua/ (in Ukr.).

Fisher, R. (1994). Introduction to the Position of Independent or Quasi Independent Agencies \& Foundations in Cultural Sector in Britain. A Report to the CIRCLE Round Table. London: Britain Publishers, 21-58.

Hrushyna, A. I. (2017). Analiz rozvytku systemy stratehichnoho upravlinnia finansovymy resursamy orhanizatsij sfery kul'tury [Analysis of the development of the system of strategic management of financial resources of organizations of the cultural sphere]. Biznes Inform [Business Inform], 1, 302-307 (in Ukr.).

Hrushyna, A. I. (2018). Osoblyvosti orhanizatsiyi systemy menedzhmentu sfery kultury ta mystetstv [Features of organization of the system of management of the sphere of culture and arts]. Visnyk Kyyivskoho natsionalnoho universytetu kultury i mystetstv. Seriya: Menedzhment sotsiokulturnoyi diyalnosti [Bulletin of the Kiev National University of Culture and Arts. Series in Management of Socio-Cultural Activities], 1, 53-63 (in Ukr.).

Pin'kovs'ka, H. (2014). Otsinka suchasnoho stanu rozvytku kul'turnoho seredovyscha rehioniv Ukrainy [Estimation of the current state of development of the cultural environment of the regions of Ukraine]. Efektyvna ekonomika [Effective economy], 10, Retrieved from http://www.economy.nayka. com.ua/?op=1\&z=3424 (in Ukr.).

Samchenko, V. V. (Ed.). (1993). Statystychnyi shchorichnyk Ukrainy za 1991 rik [Statistical Yearbook of Ukraine for 1991]. Kyiv: Tekhnika (in Ukr.).

Skrypchuk, H. V. (2012). Ohliad stanu kulturno-mystetskoi sfery Ukrainy na chas stanovlennia derzhavnoi nezalezhnosti (1991) [Review of the state of cultural sphere in Ukraine during the for-mation of the state independence (1991)]. Visnyk Kharkivskoi derzhavnoi akademii kultury [Bulletin of the Kharkiv State Academy of Culture],36, 12-21 (in Ukr.).

Skrypchuk, H. V. (2014). Derzhavne reformuvannia kulturnoi sfery Ukrainy v umovakh ekonomichnoi ta sotsialnoi kryzy 1991-2001 rr. [Government reform of the cultural sector of Ukraine in terms of economic and social crisis 1991-2001]. Avtoreferat kandydats'koi dysertatsii [Abstract of the candidate's dissertation]. Kharkiv: KhNU (in Ukr.).

Stihlits, Dzh. E. (1998). Ekonomika derzhavnoho sektora [Public sector economics]. (Trans. in Eng.). Kyiv: Osnovy (in Ukr.).

Vizand, A. (2015). Suchasni tendentsii kul'turnoi polityky v Yevropi [Contemporary trends in cultural policy in Europe]. Suchasni tendentsii kul'turnoi polityky v Yevropi : seminar [Modern Trends in Cultural Policy in Europe : workshop]. Kyiv. Retrieved from https://www.youtube.com/watch?v=TbZCzweK_fY (in Ukr.).

Received 23.09.2018 